DÁNIEL DEÁK*

\title{
Neutrality and Legal Certainty in Tax Law and the Effective Protection of Taxpayers' Rights
}

\begin{abstract}
Taxation and tax law cannot exist without biases because tax law can be seen per definition as a set of biases. Even if the state pursuing its fiscal policy cannot be neutral, one can expect to enforce the principle of equal treatment before the law. Besides, state intervention need be in proportion to the objectives of the policy of redistribution or economic stabilization. Also, fiscal policy need rely on a system of tax administration that operates in accordance with the principles of openness, good governance and legal certainty. It is ideal if the legal regulation of the procedure of tax administration is fully fledged. The legal regulation of the tax liability need be comprehensive and cover all the processes of gathering tax information, identifying the tax liability and collection of taxes. Moreover, tax administration and administrative law are inadvertently in a need of being completed by private law. Where tax authorities are not explicitly authorised by statutory law to act, they must rely on the principles that are in accordance with the constitutional order. Notably, in Hungary, there is no statutory law that would preclude the universal effect of the Civil Code, covering all the financial relations whether to be made between private persons or between private persons and the representative of the public. Finally, for the purposes of approximating an ideal tax system, the possibility of horizontal coordination must not be left out of consideration. In this context, legal and tax planning and the choice of legal and tax regimes by parties have come to the forefront. Bargaining (e.g., advance ruling) has not been strange from tax law either.
\end{abstract}

Keywords: fiscal neutrality, rule of law and due process rights, legality of the tax administration procedure, the interconnectedness of tax law with private law horizontal coordination in tax law

Taxpayer rights can be exercised effectively in a well-established system of tax law. It is important to look for the quality of tax legislation, in other words, to know about the conditions in which the tax law can be considered as ideal. It should apparently rest on a sound normative basis. For example, in the EC practice of state aid and tax competition it is crucial if certain tax law measures can be seen as part of "the nature or general scheme of the system" (Italian textile

Professor of Law, Corvinus University of Budapest, H-1093 Budapest, Fővám tér 8. E-mail: daniel.deak@uni-corvinus.hu 
industry subsidy in case 173/73). ${ }^{1}$ Yet, the question remains unfortunately open what can be considered as the general scheme of a tax system. It cannot be precluded that there are competing schemes to be found in one and the same tax system or that there are different schemes, to be seen as general, in different tax systems.

Taxation policy and law is at ever time developed according to the changing needs of the public budget and fiscal policy in general. It is thus integral part of the economic and social policy a country can pursue in specific conditions. However, scholars may have ideas about a good professional quality of tax legislation. Then one can expect that a tax system has the following features: it is

- neutral (including all the less biases);

- regulated comprehensively (there is no or minimal interim legislation);

- interconnected with (supported and completed by) private law; and

- operating not only with vertical, but also with horizontal coordination (tax planning and the choice of tax regimes are possible).

In the following, these features will be explained. Examples for (or against) the principles of a good tax system as depicted below will be delivered from the Hungarian legal practice.

\section{Theoretical considerations}

\section{Neutrality in tax law}

(i) Ideal legal system and tax law

Taxation cannot operate without legal regulation. Tax law is thus part of the law of a country. It can even appear in cross-border cases. It is thus reasonable to anticipate an ideal tax system as a tax law system, part of the legal system, whether in a purely internal or international (cross-border) context. The question of an ideal tax system is thus preceded by that of an ideal legal system.

An ideal legal system can obviously be determined by making reference to meta-juridical values. Where a legal system is oriented to right moral and democratic political values, the legal system itself will tend to operate in an ideal way. Alternatively, one cannot be pleased to be confined to non-legal values while describing a legal system. It is also necessary that the legal system itself negotiate integrity and coherence.

The law appears in the official gazette as statutory law. Moreover, it is part of an order of legal and non-legal conventions, being embedded in the traditions

\footnotetext{
${ }^{1}$ European Court Reports (1974), 709, Para 15.
} 
of the legal profession. At the same time, the law is part of the official life, being subject to the expectations of politically organized communities. This is the positive aspect of law, crucial in a society organized by means of instrumental rationality. Besides, the law is able to negotiate both legitimate interests and subjective rights in a network of recognized rights and duties. The law can eventually be substantiated by transcendental values. Examples for such an explanation can be delivered from Kelsen who referred to a basic hypothetical norm or from Rawls who introduced the notion of the so-called reflective equilibrium (to be achieved not only by bargaining, but also by reaching agreement on noumenal values). The law can also be substantiated by natural law values, yet purely procedurally, dispensing with transcendent values. This way, one can arrive at the notion introduced by Fuller of the inner morality of law.

One can see that the legal tradition can be delineated from bottom up by the layer of law directly influenced by political and ideological expectations and from top down by the high values of morality and human dignity. Any way, it is important that the law need be intact to a certain extent at least both from politics and morality. This independence is required in order to achieve consistency in the legal system and reach legal certainty.

The law can be presented not only in a course of moving from the communities organized by law to those organized by non-juridical values. The law can be described by another movement as well: it appears as a means of organized coercion, as a system of the enforcement of the respect of legal norms (like in the system of purely positive law described by Kelsen). This is the catechistic aspect-actually the hard core-of law: law appears in the body of norms that can be acknowledged and observed by means of sound reason. The law also means, however, a system of the conditions in which the interpretation of law can be authentic (as suggested by Talcott Parsons). Law is thus not only a matter of norms. It is also a matter of process. It is manifested in the aspirations to recognize and follow values inherent in the view on society of certain groups of people. Seeking for perfection is part of human life in the same way as being subjected to basic duties. This way, the law that appears in the body of norms tends to be manifested in the mind of the virtuous individual as well who will accept and follow the values negotiated by law. The latter is the aretaic (virtue-based) aspect of law.

As it can be seen, law can be delineated both in the trends of moving from positive to natural law and from the catechistic layer to the aretaic expression of law. Tax law can also be placed in the system of law as discussed above. It is integral part of the official life. It is crucial in a country to secure the collection of taxes and the administration of social justice. Taxation policy is normally subject to the fluctuation in the economic and budgetary policy. However, in a 
well-established legal system, the tax system is based on professional logic and enjoys relative independence from outward considerations. The technical aspect of tax law suggests neutrality towards political preferences.

Similarly, a good tax system can be identified not only by stressing independence from politics. It is also important to try to go beyond the enforced application of the norms of tax law and start referring to virtues. It is not voluntary to pay taxes. Coercion is thus presupposed upon the application of tax law. However, normally an agreement can be reached nationwide or even internationally on how to distribute the public burden and benefits.

It comes from the above that a good tax system tends get rid of the harmful effect of the abrupt changes in economic policy and of particular ideological considerations and move to professionalism and technicalities. Importantly, tax law need be regulated on a high level of proficiency. It cannot lack a wellestablished normative basis. This is the means of achieving legal certainty in taxation and the effective protection of taxpayer rights. However, a good tax system relies not only on coercion, but also on the propensity of people for perfection, based on a broad agreement on how to administer social justice. From this perspective, it is not only coercion, but also virtues that can be referred to upon the administration of the liability to pay tax.

(ii) Tax neutrality and its social environment

The concept of tax neutrality can be determined according to Richard Epstein as follows: "The ideal of tax neutrality simply provides that the system of taxation, as far as possible, should preserve the relative priorities that individuals attach to various activities. The function of the state is to protect liberty and property. It is not to aid one group or another in skewing the uses to which individuals put their natural endowments." 2 The approach Epstein has assumed can be criticized. In an egalitarian, market-based world, fiscal neutrality is presupposed by the consideration that equal starting chances need be secured in a social scale. The traditional idea of horizontal equity, defined as equal treatment of the equal, embodies a mistake, that is, to take pre-tax income, or consumption or wealth as the moral baseline and then try to formulate a standard of fairness, Liam Murphy and Thomas Nagel assert. ${ }^{3}$ Attention to the costs of rights leads us not only into problems of budgetary calculation, but also into basic philosophical issues of distributive justice and democratic

2 Epstein, R.: Taxation in a Lockean world. In: Coleman J.-Frankel, E. (eds): Philosophy and law. 49-74, Oxford and New York, 1987. 55; Murphy, L.-Nagel, Th.: The myth of ownership; Taxes and justice. Oxford, New York, 2002. 104.

3 Murphy-Nagel: op. cit. 163. 
accountability. The basic question is what the relationship is between democracy and justice, between the principles of collective decision-making and the norms of fairness because all that depends on collective contributions, Steven Holmes and Cass Sunstein argue. ${ }^{4}$

As in a market economy taxation is a factor inadvertently to distort economic decisions, it is a bias per definition, compared to the idea of free trade and the freedom of contracting. A tax policy can be insufficient to the particular extent as well that the implementation of tax rules will result in side effects. E.g., tax expenditures do not only suggest reduction in tax base but also trigger differences to the debit of those who are not able to benefit from tax expenditures. The alternative to a tax measure would be in this respect not to look for a better tax law measure but to seek to eliminate taxation as such. For this reason, there is no country where taxation policy could rely on a genuine normative basis, and so there is no room for discussing neutrality in taxation that would be explicated systematically.

The tax policy ideal of neutrality can be approximated by means of the economic concept of income as drafted by Georg von Schanz, Robert Haig and Henry Simons. It is comprehensive and encompassing all income as the positive differential between the stocks of financial values as measured at two different points of time. Unfortunately, even this concept of income is fraught with inconsistencies to the extent that it is difficult to reconcile the bundle of the rights of consumption with that of making savings. The same problem happens to the income generated periodically, compared to capital gains. ${ }^{5}$

As it can be seen, tax policy is always fraught with inconsistencies due to the conflict between efficiency and equity considerations and because the concept of comprehensive income itself also suffers from inherent conflicts. Given the inner constraints on tax policy formulation, tax policy cannot be justified but on a basis exceeding the scope of taxation itself. Tax policy need be assessed in the broader context of the institutional order of property, entitlements to profits and distributive justice.

${ }^{4}$ Holmes, S.-Sunstein, C. S.: The cost of rights; Why liberty depends on taxes. New York, 2000. 131.

5 von Schanz, G.: "Der Einkommensbegriff und die Einkommensteuergesetze". FinanzArchiv, 13 (1896) 1-87., Haig, R. M.: The Concept of income-Economic and legal aspects. In: Musgrave, R. A.-Shoup, C. S. (eds): Readings in the economics of taxation. London, 1966.; Simons, H. C.: The comprehensive definition of income. In: Houghton, R. W.: (ed.): Public finance; Selected readings. Harmondsworth, 1970. 38-45. 
Where tax policy is subject to contradictions for objective reasons even in the time of economic prosperity, it is in a need of seeking for mitigation. It is public administration, or rather tax administration and tax law, which can be mentioned among the factors that can provide such mitigation. Good public administration can largely promote the easy enforcement of taxpayer rights. The efficiency-based standards of a market economy cannot be implemented without non-economic considerations. It is thus important to try to avoid falling into the trap what is called by Schumpeter as a Ricardian vice, that is, to pursue economic policy without taking into account the institutional environment. ${ }^{6}$

In taxation policy, the issues of allocation and distribution need be distinguished from each other. The first question concerns the size of redistribution, the second one the way in which redistribution can take place. It is illusionary to think about a private economy that would be just as long is it is not subject to budgetary policy and that redistribution would suggest a bias from a notional benchmark. One has to take into consideration ${ }^{7}$ that

- it is reasonable to seek to achieve vertical equity (there are reasons for apportioning the cost of public expenditures unequally among those with unequal resources);

- the term of public goods implies a social structure which need be balanced; and

- the provision of a social minimum should be accomplished by transfer payments.

Apparently, there is no market without state and there is no state without taxation. ${ }^{8}$ From this perspective, it is clear that neutrality in taxation can be legitimized on a high level of libertarian abstraction only, isolated from its social environment.

A search for tax policy options includes the paradox that a course of tax policy cannot be assessed taken by itself, or rather that a tax policy question cannot be expected to be answered but after having examined taxation within an institutional framework that goes beyond taxation itself. In considering the economic foundations of the social life, the first question that arises is that of property. Thus, the question can be raised what relationships are among people developed upon the acquisition and disposal of the single objects of nature.

${ }^{6}$ Backhaus, J. G.: Legal and economic principles for the common administrative law in Europe. In: Marciano, A.-Josselin. J.-M. (eds): The economics of harmonizing European law. Northampton, MA, 2002. 249.

7 Murphy-Nagel: op. cit. 94-95.

${ }^{8}$ Murphy-Nagel: op. cit. 32. 
The right to ownership can be derived from natural law, or even from the fundamental moral requirement that everyone has the right to follow a life worthy for a human being. This means in practice the right to get access to the minimum of social protection. What is expressed by the positive law-as property rights-suggests more and belongs to the realm of decisions motivated by ideologies.

From the viewpoint of general economic policy, in addition to property and the private and public forms of the mechanisms of the appropriation of goods, one has to pay attention to the institutions of the centralization of social production and the redistribution of surplus value. They can be studied from the viewpoint of different theories. In an approach based on formal and immanent values, the review of specific historic circumstances is underestimated. In this respect the development of property is seen simply as an incidental question of "first occupation". So, the considerations of justice and morality cannot be raised (like with Hume or Coase). In an approach established on formal and transcendental values (Kant), property is, even though isolated from specific historic circumstances, deemed to develop due to the noumenal will of universal nature that emerges over individual wills while generating norms.

In an approach based on material and immanent values, the acquisition of property can be legitimized by means of a presumptive social contract (like with Rousseau) or by reference to the individual performance of work (Locke). In the former case, it is not possible to get rid of being compelled to maintain enforcement mechanisms of equality or rather direct and permanent state intervention. The frictions arising from these constraints can be mitigated, provided, however, that it is not directly goods that are distributed. Instead, distribution need be preceded by the preliminary choice of certain social institutions (i.e., rights or basic liberties like with Rawls). Individual appropriation can be interpreted in a social environment, although not necessarily supported by positive rights. This is because the appropriation of natural objects is allegedly possible without the intervention of the law or the institutional system of the state. In an approach based on transcendental and material values, it is not only the person, identifying himself or herself by means of ethical or religious values, who can be highlighted, compared to individuals orientated merely by their financial interests. In modern times, the social practice susceptible to transcendental values can also be substantiated during the distinct processes of ethical discourses in the instance that those who observe a situation and those who are observed cooperate in determining the effective order of values relevant to individual cases. 


\section{The rule of law and legal certainty in taxation}

(i) The emerging notion of administrative law

Tax administration is part of public administration. It is therefore a question of tax administration, in addition to the enforcement of the tax law vis-a-vis the taxpayer, of how to operate tax administration as an organization. Modern public administration is governed by the principles of openness, good governance and legal certainty. The principle of openness suggests that public administration is expected to be open to democratic values and to support the participation of citizens in the management of public matters. The idea of good governance can be traced back to the requirement that public administration need be transparent. For tax law purposes, it is the principle of legal certainty, which is of particular relevance. The tax authority as an agency of public administration is bound to the law (subject to legality) while entering into a relationship with the taxpayer who may exercise in the procedure of tax administration the rights of a client.

The above principles are generally applicable in western societies, even if differences can be developed in different jurisdictions. In France, public administration is provided with prerogatives. This is from which the rights of administrative agencies are emanated to exercise discretion. Discretion is still subject to legality. In Germany, administrative agencies are also allowed to exercise discretion. They are subject, however, to the requirement that the individual rights of citizens need be protected. In common law jurisdictions, public administration is traditionally not subject to legal regulation. However, the decisions of administrative agencies are subject to judicial review. These decisions will be assessed by courts in the light of due process rights. ${ }^{9}$

Substantive administrative law was developed at the modern time when it became necessary to depart from normal civil law provisions in order to create a legal background for the state liability. This law has been evolved alongside with the reduction and precision of state immunity. Administrative law was developed in France as long as it was necessary to implement and specify in the practice of public administration the constitutional principle of the division of power into the branches of legislation, administration and the judiciary power. ${ }^{10}$ In fact, it was important to determine the conditions in which the

9 Harlow, C.: Global administrative law: The quest for principles and values. The European Journal of International Law, 17 (2006) 190-192.

${ }^{10}$ Schwarze, J.: Europäisches Verwaltungsrecht; Entstehung und Entwicklung im Rahmen der Europäischen Gemeinschaft, Baden-Baden, 2005 (2. erweiterte Auflage; 1. Auflage in 1988), 97-98. 
decisions of public authorities can be challenged before court. To this end, the courts of public administration were established with competences different from those of normal civil courts. The courts with the particular power of making the review of public authority decisions were in a need of a material of substantive administrative law. Substantive administrative law has thus been developed due to the distinction of the courts of public administration from civil court. In Germany, substantive administrative law has been the result of the specification of the principles of constitutional law with regard to the protection of subjective rights. More importantly, the law of public administration is designed to represent a kind of permanency compared to the political values, subject to fluctuation, that can appear in terms of constitutional law.

In common law systems, public administration was not covered by a particular legal material for a long time due to the lack of the division of the legal system into the branches of civil and public law. The law was invoked by citizens before normal courts, depending on their claims, no matter whether of private or public law nature. By the time when the state has undertaken to assume responsibility for the administration of social welfare by the means of public law, the independent material of administrative law has also been developed. In North America, public administration was already in the early 20th century expected to develop regulatory power (to exercise review over tax administration, securities exchanges, anti-trust, consumer protection, etc.). In the UK, the branch of administrative law has been developed much later. In America, the development of administrative law also received fresh impetus due to the adoption of the Federal Administrative Procedure Act of 1946, missing in England. ${ }^{11}$

(ii) Rule of law and due process rights

From a sociological point of view, the rule of law principle concerns the issue of the law and its social environment. In this respect, one can distinguish four types of relations between the legal system and its social environment:

- undifferentiated (archaic) system;

- subordinate (e.g., feudal) system;

- autonomous system; and

- partially independent system.

The latter means procedural independence, that is, a case where the system is sufficiently insulated to permit independence in some spheres, but not so protected as to prevent adaptive responses to the needs of other sectors of the

\footnotetext{
${ }^{11}$ Schwartz, B.: Administrative law. David L. Sills (ed.): International encyclopaedia of the social sciences, Vol. 1, Basingstoke, Hants, 1968. 79-80.
} 
society. ${ }^{12}$ The law is thus functionally differentiated as a system, while preserving its ability for communication with its environment as a self-referential system. In this context, the principle of the rule of law can be interpreted as a kind of guarantee for the functional differentiation of the law as a subsystem of society.

For the lawyer, it is more common to grasp the notion of the rule of law from the viewpoint of natural law rather than from the perspective of sociological functionalism. An example for this natural law-based approach is delivered by Albert Dicey who holds: "We mean ... that no man is punishable or can lawfully be made to suffer in body or goods except for a distinct breach of law established in the ordinary legal manner before the ordinary courts of the land. In this sense, the rule of law is contrasted with every system of government based on the exercise by persons in authority of wide, arbitrary, or discretionary powers of constraint"; ${ }^{13}$ Quite similarly, the rule of law as "Rechtsstaat" means the following: ${ }^{14}$

- independence of the law from politics;

- a system that is based on the respect of human rights and liberties; and

- being different from the political system, a kind of predictability and regularity.

In fact, the rule of law does not have the same meaning, of course, in such countries as England and Germany, so much different from each other. In a traditional common law system, the rule of law negotiates a criterion according to which the legality of the decisions of public authorities can be measured with regard the protection of subjective rights. The legality of the claims established before the court can be assessed not to the (statutory) law that exists beforehand, like on the European continent, but it is compared to relevant legal rules and principles developed from case to case.

In Hungary, legal rules can be declared as unconstitutional on the sole grounds that the rule of law principle is infringed. ${ }^{15}$ This means

- first that the rule of law is a meta-principle that is of significance for the purposes of the operation of the whole legal system; and

\footnotetext{
${ }^{12}$ Mayhew, L.: II. The legal system. Sills, D. L. (ed.): International encyclopaedia of the social sciences, Vol. 9, Basingstoke, Hants, 1968. 61-62.

${ }^{13}$ Long, N.: II. The administrative process. Sills, D. L. (ed.): International encyclopaedia of the social sciences, Vol. 1, Basingstoke, Hants, 1968. 68.; Dicey, A, V.: Introduction to the study of the law of the Constitution. London-New York, 1964 (1885; 10th edition), 188 .

${ }^{14}$ Leibholz, G.: Der Rechtsstaat und die Freiheit des Individuums. Meyers enzyklopädisches Lexikon, Band 19, Mannheim, 1977. 677.

${ }^{15}$ Sólyom, L.: Az alkotmánybíráskodás kezdetei Magyarországon (The origins of the constitutional judiciary activity in Hungary). Budapest, 2001. 706.
} 
- secondly that it is not required to refer to particular legal rules in addition to the rule of law principle in order to enforce subjective rights.

The notion of legal certainty is in the heart of the concept of the rule of law. It can be seen not simply as part of the rule of law. Instead, the principle of legal certainty can be considered as the particular manifestation of the rule of law principle, László Sólyom asserts (who was the first president of the Hungarian Constitutional Court).

The rule of law is guiding not only for the constitutional order in general, but also for the organization of public administration in particular. Even the democracy principle cannot be respected where the rule of law is not observed. The focus on due process rights triggers the appreciation of procedural issues. Substantive law problems have been all the more converted into procedural law issues (an example for this is in the tax law area to file for advance rulings). In common law jurisdictions, this is a normal development. On the European continent, proceduralization can be imputed to the general trend of development that distributive justice has been converted into procedural one in many instances. The respect of the due process principle has received particular impetus in Community law where the principle of legitimate expectation has been proliferated.

Due process rights are incorporated into the Hungarian law of public administration by Section 4 (1) of the Public Administrative Procedure Act. They are formulated as the right to fair trial. Due process rights have been protected by the EC Court of Justice as well since the early time. ${ }^{16}$ They are recognised in a range of international law documents as well that can be enumerated as follows:

- Universal Declaration of Human Rigths, Article $10 ;{ }^{17}$

- European Convention on Human Rights, Article 6; ${ }^{18}$

- draft of the European Charter of Fundamental Rights, Article 41. ${ }^{19}$

Due process and related rights emerge in the practice of the European Court of Human Rights in implementing ECHR in tax matters as well. Article 1 (2) of Protocol No. 1 of ECHR on the protection of property cannot be applied to tax matters as such, being of public law nature. However, the question can

\footnotetext{
${ }^{16}$ Early examples for the application of these principles are 222/84 Johnston, ECR 1986. 1651.; 222/86 Heylens, European Court Reports, 1987. 4097.

${ }^{17}$ Adopted and proclaimed by General Assembly resolution 217 A (III) of 10 December 1948.

${ }^{18}$ European Court of Human Rights signed at Rome on 4 November 1950; Protocol No. 1, signed at Paris on 20 March 1952.

${ }^{19} 2000$ OJ C364/01.
} 
be raised whether tax legislation is consistent with the principles of legal certainty, proportionality and the duty to give reasons for the decisions of public administrative agencies. In the matters of tax administration, the usual issue that can appear before this court is, of course, Article 6 ECHR on fair treatment. However, it does not apply to tax administration. This is because the review of the decisions of tax authorities before courts is precluded from the application of Article 6. It can still apply exceptionally, that is, to the extent that the legal nature of the administrative procedure itself can be challenged. For example, it can apply to the question whether the administrative procedure at issue was too lengthy or the tax authority was not correct in applying sanctions. Article 14 ECHR on non-discrimination, Article 8 ECHR on the respect of privacy or Article $9 \mathrm{ECHR}$ on the freedom of conscience can also be taken into account in tax matters. ${ }^{20}$

In common law systems, the public administration is expected to operate in accordance with the principle of due process (a principle of natural justice or fairness) which is a procedural guarantee for the legality in the operation of public administration. As the principle of due process means the higher criterion of legality according to which the administrative procedure can be assessed with regard to the protection of individual rights, there is no existing statutory law by which it would be preceded. Where the idea is to apply this principle in a civil law system, however, it can be problematic that one has to encounter the existing statutory law provisions which are not necessarily in accordance with the conclusion that can be made as a result of the application of the due process principle.

The due process principle has been built recently in civil law systems, now as part of the relevant statutory law system. The problem cannot be avoided, however, that it would be required to explain why a universal rule, uttering the due process requirement, could take priority over particular legal rules which are otherwise valid. The due process principle can be placed smoothly in a common law system because such a legal system is open to outward values that can be digested and transformed into law from time to time. In contrast, a civil law system is not open to non-legal values. They cannot be integrated unless they will be made explicit law in a particular procedure of legislation. Similar problems of the application of a principle of natural justice can be realised where the true and fair view principle is applicable in the accounting law of a civil law system. Again, consistency problems between the valid particular legal rules and the higher-level principle seem to be inevitable.

${ }^{20}$ Baker, Ph.: Taxation and the European Convention on Human Rights. European Taxation, 40 (2000) 299. 
In the light of openness, public administration has created new fora of democracy in terms of the so-called deliberative polyarchy. ${ }^{21}$ In the arena of European bureaucracy, a kind of public administration can be created which is directly established on deliberation and operates in a pluralistic political system. It promises to substitute deliberative techniques for the missing political consensus of Member States to create a genuine organization of the people's representation at a federal level. Under such circumstances, public administration implies the possibility of introducing procedures by means of which conflict-laden substantive matters can be handled. The comitology developed by Community institutions contributes to the development of the patterns of deliberative democracy. ${ }^{22}$ There is a line of European bureaucrats, and the representatives of professions and the organizations of interests safeguarding who can initiate communication with a view to achieving checks and balances even in the absence of political authorisation.

The idea of good governance derives mainly from the liberal movement of the so-called New Public Management (NPM). It is comparable to the socalled New Economy (e.g., networking industries, environmental protection, etc.) to the extent that it can be traced back in the same way to deregulation and privatization. ${ }^{23}$ The measures of public administration, and the interests associated with them, can be differentiated similarly to the requirement of unbundling relevant to competition law. The goal to be achieved is thus to prevent public administration from concentrating too much power of decision by differentiating the single forms of activities. As a result, the structure of activities will be more transparent and discretion can be replaced by the technically-minded, semi-automated forms of public supervision. Notably, Community institutions do not enjoy universal authorisation. Instead, they may act, based on the specific conferment of power. In these circumstances, professional expertise is to be pooled both on the side of public and business administration.

\footnotetext{
${ }^{21}$ Harlow: op. cit. 201.

${ }^{22}$ Report from the Commission on the working of the Committees during 2001, COM (2002) 733 final.

${ }^{23}$ Giuliano Amato and Laraine Laudati: The protection of public interests and regulation of economic activities. In: Snyder, F. (ed.): The Europeanisation of law: The legal effects of European integration. Oxford-Portland-Oregon, 2000. 142.
} 


\section{The interconnectedness of tax law with private law}

Acts of public administration are designed to trigger specific legal consequences to be associated with the facts of the past in particular forms. They are not necessarily regulated by the law of public administration (for example, the acts of the agencies of public administration as employers are covered by labour law). These acts are not always dispositions, that is, one-sided decisions of public agencies on the determination of rights and obligations (for example, the agencies of public administration can enter into agreements with private parties). It can be seen from these examples that the agencies of public administration cannot be intact from private law, which is applicable in normal circumstances to all pecuniary relations, no matter what the legal status of the affected person is. In tax law, the enforcement of the logic of civil law can be seen paradoxically very normal. Although tax law negotiates the liability to make payment to the state budget, it is the market players who are liable to pay tax. While observing tax law, they consider to optimize their structures of business in order to minimize the liability to pay tax, although within legal boundaries.

Where it is doubtful if a legal institution is of public or private law nature, one can rely on a doctrine known in Germany according to which the obligation of public law cannot be recognised unless it is explicitly covered by statutory law. ${ }^{24}$ If not, it is the private law principles that are guiding. In a democratic political system, everything is free what is not prohibited. Furthermore, people are bound to the promises they made (pacta sunt servanda). One can argue: in the absence of positive public law provisions, public law cannot be enforced, and it is the civil law principles in the light of which the legal implications for particular cases can be assessed. Public law regulation is inadvertently subject to the guidance private law can provide. This is because it is not possible that public law is addressed to all details in a changing world. Then it is the private law principles of the respect of personality, property and contractual promises only that can be authoritative. Public agencies do not have the power to act unless they are explicitly authorised to do that in particular conditions. Based on the principle of subsidiarity, civil law considerations are the very basics of the conduct regulated by law. The agencies of public administration are bound to contractual obligations in the same way as private persons. They can be enforced by law even if it is burdensome for the public body. Democracy cannot operate but within the boundaries of the rule of law.

\footnotetext{
${ }^{24}$ Verwaltungsrecht, Band 1, begründet von Hans J. Wolff, fortgeführt von Otto Bachof, neu bearbeitet von Rolf Stober, C. H. München, 1999, elfte, neubearb. Auflage, 267.
} 
In common law systems, the law has not been structured as clearly according to the different branches of private and public law as the case is in civil law systems. The question is therefore not reasonable if private law principles can serve as a background for the public administration to fill the gaps arising from the legal rules relevant to its operation. Albert Dicey is categorical in this respect: "in England ... the system of administrative law and the very principles on which it rests are in truth unknown.". ${ }^{25}$ The point to the rule of law is highlighted by Dicey ${ }^{26}$ not only in terms of the public administration subject to laws. The principle of the rule of law also implies

- the unity of the legal system, and the exclusion of the possibility accordingly that a branch of administrative law could be distinguished; and

- the statement that the constitution is nothing but the consequence of the application of private law, binding both to ordinary courts and the agents of the crown.

It is noteworthy, however, that tort liability of the state is excluded due to the state immunity doctrine, and this is the case until the adoption of the Crown Proceedings Act of 1947. The legal system as described by Dicey provides nevertheless room for the application of the "pacta sunt servanda" principle in a more ideal way than it can happen wherever else.

Substantive law has been developed in England in correspondence with particular legal actions. For example, the decisions of public authorities could be challenged by claiming "orders of certiorari" (lodging objections to administrative decisions), "prohibition" or "mandamus" (claiming administrative inaction or action, respectively). These legal actions were different from those to be filed in the forms of "damages", "declarations" or "injunctions". Since 1978 the above distinction has lost its significance due to the unification of legal actions. ${ }^{27}$ It is useful, however, to remember them in order to get deeper understanding between the normal and special competences of courts in the matters of public administration.

In France, it has been the standard already since the Blanco decision (T.C. 8.2.1873. G.A. No. 1, S. 5.), as held by the Tribunal des Conflits that the state liability need not be assessed according to the Code Civil, but according to the "règles spéciales qui varient suivant les besoins du service et la nécessité de concilier les droits de l'Etat avec les droits privés". ${ }^{28}$ Hence, it has been the practice that the matters of public administration are to be discussed by the

\footnotetext{
${ }^{25}$ Schwarze: op. cit. 133.; Dicey: op. cit. 330.

${ }^{26}$ Schwarze: op. cit. 133.; Dicey: op. cit. 188., 193 and 195, respectively.

${ }^{27}$ Schwarze: op. cit. 140-141.

${ }^{28}$ Schwarze: op. cit. 98.
} 
special courts of public administration (recours administratif), and a resort to civil courts (recours contentieux) is in the matters of public administration exceptional.

In Germany, there are special courts of public administration as well. However, they do not derive from the needs of the legal review of the decisions made by public administration, but rather from the need of implementing the constitutional principles. It is exceptional also in Germany that citizens have a resort to civil courts in the matters of public administration (this is the case, e.g., in the matters of expropriation).

In Hungary, public law has been departed from private law in a similar way as in Germany. It is thus based on the distinction between the branches of substantive public and private law. Although there are no special courts of public administration in this country, one can find particular chambers of the normal courts specialising in the matters of public administration, and the Civil Procedure Act also contains particular rules applicable to the litigation between public authorities and citizens, challenging the decisions of public authorities. However, civil law has net been broken down into as many different branches as the case is in many other jurisdictions on the European continent. In particular, no code or doctrine of commercial law or business law has been recognised in this country that would be different from civil law. This way of historical development may suggest more chances for the application of the civil law principles (prohibition of the abuse of law, theory of estoppel, etc.) even in the matters of public administration than in civil law systems which are more structured than the Hungarian one. Notably, the Hungarian Civil Code is applicable to financial relationships of anybody without limitation. No particular law can thus be ascertained according to which this universal effect of the Hungarian Civil Code would be constrained.

In Italy, distinction between the competences of the courts of public administration and civil courts has also been recognised in the matters of public administration, and even supported by the well-established doctrine on the distinction between the matters related to the protection of legitimate interests (interessi legittimi) and subjective rights (diritti soggettivi). In the first case, it is normal that the courts of public administration are competent. In the second case, however, it is possible to get resort to civil courts. ${ }^{29}$

Distinction between the competences of normal and special courts in the matters of public administration is problematic in general in modern legal systems. This is because it is difficult to reconcile such a distinction with the trend of development of the modern law that legal actions have been unified

${ }^{29}$ Schwarze: op. cit. 128; Nigro, M.: Giustizia amministrativa. Bologna, 1983. 115-116. 
(ubi remedium, ibi ius). However, the legal orders that exist out of the reach of the nation state may well rely on particular legal actions. For example, under Community law there are particular legal actions (in infringement procedures, annulment procedures, etc.). Also, the European Court of Human Rights can be mentioned which does not have competence in public matters with the exception of the cases where citizens are prevented from exercising their basic rights due to the disorder of public administration or legislation.

In the Netherlands, public and private law have been clearly separated from each other already in the 19th century. The principle was also developed at the turn of the 19th and 20th centuries that public law was of complementary and exceptional nature, compared to private law which had universal effect. This is the pure expression of a "Vermutungstheorie". However, this theory has been given up in accordance with the development of the state responsibility for the administration of social welfare. Hence, currently the legal review of the decisions of public administration can purely be established on the rules of public administrative law.

\section{Vertical and horizontal coordination in tax law}

Law cannot be confined to what is applied by force, that is, by means of public coercion. Indeed, legal compliance is to be presupposed first in terms of vertical co-ordination where the nation state determines the way in which sacrifice need be made for the public. Law also suggests, however, functioning as a means of promoting bargaining. This is the aspect of horizontal co-ordination. ${ }^{30}$ Law can be identified this way in the sense that consistency and coherence can be achieved in a functional system where the facts of particular cases are juridified due to the self-regulatory force of the parties involved in particular cases. $^{31}$

Law is indeterminate to the extent that the conduct of individuals cannot be necessarily imputed to the legal norm. Law cannot be understood simply by studying legal norms. It is also important to try to understand the individual conduct effectuated in compliance with law. It is then possible to turn back to the legal norm and try to explore its meaning. It occurs frequently that the schemes invented by companies (e.g., innovation in financial products, planning

\footnotetext{
${ }^{30}$ Zürn, M.: Introduction: Law and compliance at different levels. In: Zürn, M.Joerges, Ch.: Law and governance in postnational Europe; Compliance beyond the nationstate, Cambridge, 2005. 6.

${ }^{31}$ Joerges, Ch.: Compliance research in legal perspectives. In: Zürn-Joerges (eds.): op. cit. 221.
} 
hybrid entities, etc.) shed light on the problems of legal interpretation. Then the legislation is expected to react in the affirmative to the innovation achieved in legal practice.

Tax law compliance cannot be reduced to the issue of vertical co-ordination. While on the surface tax law seems to be extremely categorical, in fact taxpayers enjoy much freedom in choosing the tax law status, depending on what is more beneficial for them. The specific tax law consequences can be traced back to the horizontal activity contracting parties show in their pre-tax life. Tax rules cannot be understood clearly, but from the perspective of the taxpayers' conduct, oriented to tax planning. The taxpayer conduct is a test of the enforcement of tax law.

Tax legislation heavily relies on the economic policy considerations a government prefers in certain circumstances. Tax law can then be changed where there are alterations in economic policies. Tax law facts are actually emanated from the annual budget law. It is required, however, that the creation of the tax liability can be independent of the abrupt changes in budgetary policies.

Election of tax regimes has been all the more frequent. For example, in accordance with the EC Merger Directive, taxpayers may elect to defer the taxation of the capital gains derived from the contribution of the appreciated branch of assets and liabilities, provided that no step-up will be made in the financial attributes like the acquisition price of tangible assets taken over from the branch (roll-over relief). In sophisticated tax systems, the election of a tax regime has been significant. The best example for this is the check-the-box rules in the US federal tax law. ${ }^{32}$ Taxpayers can thus elect in certain conditions whether they enter the system of company taxation or choose to be taxed at the level of shareholders. The introduction of such statutory election comes from the experience that statutory law is sometimes not flexible enough. The rigid categorical order of tax law provisions prevents taxpayers from achieving high compliance with tax law.

Election can be hosted by a national tax system only where the legal culture implies the possibility of providing alternatives in legislation and legal rules of facilitating nature. In Hungary, it would be more than difficult, for example, to introduce a tax regime like the check-the-box-rules. This is because a corporate taxpayer is not identified according to the economic contents of the activities carried on. Instead, there is an exhaustive list of corporate tax payers who are identified by reference to their non-tax law status. It depends on the civil-law qualification whether an entity is subject to corporate taxation. This is

\footnotetext{
3226 C.F.R. Sec. 301.7701 of Treasury Regulations.
} 
a practice that can be far from the reality of living business. A civil law association, not subject to company tax, can be engaged in significant business while small companies are subject to company taxation, whether they like it or not.

\section{Hungarian issues}

\section{Legality of the Hungarian tax administration procedure}

According to Section 4 (1) of Taxation Order Act, taxation means a procedure in which the taxes and subsidies payable by, or repayable to, taxpayers are managed in terms of the determination, collection, transfer or return, and audit of taxes by tax authorities. Taxation is covered by the Act on the Procedure of Public Administration unless a tax law, including the Taxation Order Act, provides otherwise [Section 5 (1) of Taxation Order Act]. The Act on the Procedure of Public Administration is addressed to the procedure (or rather jurisdiction) of, and the services provided by, the agency of public administration. The procedure of the agency of public administration, different from the simple procedure of public administration, envisages the relationship to be established between the agency of public administration and the client (the private party to public administration) which is covered by law. This is a procedure, in which the agency of public administration explores the facts relevant to the legal qualification of the case brought before the agency, and at the end of which the public agency arrives at a formal decision. The procedure of public administration cannot be interpreted in Hungarian law as other than a procedure of an agency of public administration. The rights and obligations of both parties to the procedure of public administration are emanated precisely from this procedure of the agency of public administration.

In contrast, in tax matters, a procedure of public administration other than a procedure of an agency of public administration cannot be precluded. Under Section 85 of Taxation Order Act - a procedure of tax administration can take place in which the tax authority (i) determines the taxpayer's rights and obligations, (ii) makes an audit of the performance of tax liabilities, and (iii) keeps records on the facts relevant to the tax liability. This is a procedure, different from a tax authority (agency of public administration) procedure. In the procedure of tax administration, not identical to a tax authority procedure, the tax authority deals with the matters enumerated as items from (ii) - (iii). In the tax authority procedure, the tax authority is responsible to deal with the matters enumerated as item (i). The tax authority procedure as regulated by Section 120 of Taxation Order Act covers the determination of the tax base, 
the tax (advance tax) and the tax relief, if any, the right to receive subsidies and to get access to the return of taxes. A tax authority procedure usually appears as a result of the determination of the unpaid tax following the completion of a tax audit. The tax liability can also be determined by the tax authority in extraordinary cases or in terms of advance rulings. In addition, a tax authority procedure can imply the management of tax records. A tax authority procedure can normally be initiated "ex officio" where the tax authority decides for keeping tax records or the determination of the tax liability. The tax authority procedure can also start upon the taxpayer's request. Then the tax authority decides for keeping tax records or for the reduction of the tax liability by equity reasons or for the reason of allowing the payment of tax in instalments.

Where tax audits are conducted and tax records are handled in a simple procedure of tax administration, the taxpayer does not enjoy a higher level of legal protection, which would be granted to the taxpayer in a tax authority procedure only. This is because in the latter case the taxpayer is provided with the client's rights and duties and may challenge the tax authority's decision arrived at the end of this procedure, first at a higher instance of tax administration, secondly, before a court. During a tax audit, and in the procedure where tax records are managed, the taxpayer cannot enjoy the status of a client. As a consequence, the taxpayer cannot meet the tax authority's formal decision that could otherwise be challenged at a higher instance. One can conclude therefrom that the procedure of tax administration as regulated in terms of the tax audit and the management of tax records is subject not only to legal considerations, but also to the considerations of efficiency.

Apparently, tax authorities take decisions both in terms of the procedure of tax administration (e.g., during a tax audit) and of the tax authority procedure. In the first case, they may take important decisions, for example, while exploring the facts relevant to the tax liability. For example, the tax authority may decide for the application or non-application of certain means of evidence. The taxpayer, whether agrees or not on these measures, is not able by law to prevent the tax authority from taking such decisions. As a maximum, the taxpayer may make comments on the tax authority conduct in the proceedings at the end of the procedure of tax audit. In later stages of the tax dispute, both the higher-instance tax authority and the court heavily rely on the evidence produced by the tax authority during the audit, not still covered by a higher level of legal protection. At a later stage, the dispute between the tax authority and the taxpayer can hardly be solved as to whether the tax authority has observed its obligation plainly to explore the facts relevant to the tax liability or that the taxpayer's conduct has been consistent with the obligation of good 
cooperation with the tax authority. It would be easier to administer justice in these matters if even the tax audit is subject to a tax authority procedure. One can realise that during a procedure of tax administration other than tax authority procedure, the measures taken by the tax authority are legally regulated as interim ones, even if they may be of high importance for the purposes of the final decision of the tax liability.

Based on the above, one can criticise, for example, the provision of Section 93 (1) of Taxation Order Act on the commencement of tax audit. The tax authority is by this provision not obliged to arrive at a formal decision of the commencement of tax audit. The tax authority is even not obliged by law to inform the taxpayer of the commencement of audit. This provision is not subject to criticism as to its contents. It is problematic, however, that the tax authority's right to take such a decision is not regulated by the Taxation Order Act precisely. It would be reasonable to provide in detail for the conditions in which the tax authority may take such a decision.

In Hungarian law, the taxpayer is not allowed to initiate a dispute concerning the legality of the tax liability without making a tax return with zero tax liability. Failing to declare tax liability, the taxpayer is not able to get rid of the determination by the tax authority of the unpaid tax and the application by the tax authority of sanctions, associated with the unpaid tax. A solution for the problem would be either that the taxpayer could file a tax return with the reservation of the right to challenge the validity of the tax liability or that the taxpayer could opt out of self-assessment by asking the tax authority to determine the tax liability by a formal decision. None of these opportunities is currently available in Hungary for taxpayers, however.

According to Section 124B of Taxation Order Act, the taxpayer may make self-audit by raising the only issue whether the legal basis for the tax liability as assessed is legal. Then the tax authority confines itself to dealing with this only issue. Where the tax authority does not agree on the taxpayer's standpoint as reflected in the tax return, decides for the unpaid tax. Then a tax authority procedure commences in which the taxpayer can challenge the tax authority's standpoint even up to the instance of a court decision. Nevertheless, the taxpayer cannot avoid even in this case assuming the risk that the unpaid tax will be identified.

Interim decisions may well affect the position held by the taxpayer, even if not eventually. Both the taxpayer and the tax authority may be engaged in taking interim measures. ${ }^{33}$ The taxpayer may not change the assessment of the

${ }^{33}$ González, E.: The administrative procedure for determining tax liability. In: Amatucci, A. (ed.): International tax law. Alphen an den Rijn, 2006. 127. 
tax liability but via a tax audit, decided not by the taxpayer, and the taxpayer may not change his or her decision taken as a result of a self-audit. The tax authority cannot change it decision either but in specific conditions as determined by law. The tax authority, realising that it deems to be necessary for any reason to change its decision, may make the amendment or revocation of its former decision within the conditions as determined by Section 135 (1) of Taxation Order Act.

\section{The example of Hungary for the interplay between tax law and civil law}

The Hungarian law on tax administration (Taxation Order Act) suggests more than regulating tax administration only. Similarly to the German law pattern of "Abgabenordnungsgesetz", ${ }^{34}$ it implies the general part of tax law, compared to the particular laws on single taxes. This general part implies the common legal rules on the facts of a tax law case (Tatbestand), that is, on the taxpayer, the taxable basis, the tax rate, the possible tax relief and the way of tax collection. The legal regulation of tax law-related facts is of importance even for constitutional purposes. For example, general tax law may provide for the prohibition of confiscation. The Hungarian general tax law as appears in terms of the Taxation Order Act is extended to the major principles of taxation. Placed into a block of provisions, these principles are appropriate for constituting a basis for the taxpayers' rights, even if it does not contain a broad catalogue of taxpayer rights.

The Taxation Order Act provides for that both taxpayers and the tax authority are bound to legal provisions. It also asserts the principle of legal certainty [Section 1 (2)]. The tax authority shall exercise its right of discretion within the boundaries of equity [Section 1 (6)]. It must not treat taxpayers in a discriminatory manner either [Section 1 (3)-(4)]. Both the tax authority and the taxpayer shall act in good faith [Section 1 (5)]. This implies the legal obligation that the parties to tax administration shall act in co-operation. This is similar to the contracting parties who shall by civil law act in co-operation as well. The Taxation Order Act prevents taxpayers from getting involved in tax avoidance, invoking two principles. First, simulated transactions must be disregarded for tax law purposes [Section 1 (7)]. This is designed to solve the conflict between the legal form the parties apply on the surface and the real legal form, which is concealed. Secondly, the legal form must be disregarded where it does not reflect the economic contents of certain transactions [Section 2 (1)]. This is designed to solve the conflict between the legal form and the

\footnotetext{
${ }^{34}$ Abgabenordnungsgesetz vom 29. August 1997 m. mehrf. Änd.
} 
economic contents of the same transactions. The tax authority is free to arrive at the tax law qualification consistently with the economic contents, no matter what the civil law form as applied by parties suggests. The tax authority is obliged, however, to take into account both the civil law and tax law aspects of a tax avoidance case related to the problem of simulation. The tax law issue cannot thus be extricated from the civil law question of simulated contracts.

Where taxpayers notify certain facts to the tax authority or disclose their particulars to the tax authority, they remain to be protected by civil law. The tax authority is thus obliged to keep the data communicated by taxpayers confidentially and manage them in accordance with the civil law protection of personality. Even the tax authority may claim by tax law the protection of personality. Section 55 (1) of Taxation Order Act provides for that the tax authority may before the public rebut the information the taxpayer has delivered and the tax authority thinks to be false and appropriate to shake the faith in the tax administration before the public. Another link of tax law to civil law is that the calculations used in accounting law can be relevant to the tax liability. Since commercial accounting is part of the civil law, broadly speaking, this is another piece of evidence for the close connection of tax law with civil law.

Apparently, advance rulings-as a matter of bargaining-are managed in accordance with civil law standards. This is an example for the case where substantive law problems are converted into procedural ones. In this instance, public law prescriptions cease to operate and will be replaced by private law techniques of dispute resolution. Again, the fact that tax authority decisions can be challenged before civil courts suggests the interconnectedness of tax law with civil law. The significance of civil law as a background has been enhanced by the EU accession of Hungary to the extent that the malfunction of both the fiscal legislator and the tax authority can be sanctioned in terms of the compensation (or restitution) for damages, to be regulated by the Civil Code in Hungary.

\section{Summary and conclusions}

Taxation and tax law cannot exist without biases because taxation can be seen per definition as a set of biases. The question can only be posed if a tax system can rest on a sound normative basis with the possibly least interference with the decisions of market players, yet with enough allocation and just redistribution of the tax burden with regard to the protection of the poor. Even if the state pursuing its fiscal policy cannot be neutral, one can expect to enforce 
the principle of equal treatment before the law. Besides, it must not apply means that are not absolutely necessary in order to achieve the legislative goals. State intervention need thus be in proportion to the objectives of the policy of redistribution or economic stabilization. Furthermore, the law of taxation is expected to show stability. Also, fiscal policy need rely on a system of tax administration that operates in accordance with the principles of openness, good governance and legal certainty.

Furthermore, it is ideal if the legal regulation of the procedure of tax administration is fully fledged. In other words, it is not ideal where for example the process of tax audit is covered by interim legal measures only. The legal regulation of the tax liability need be comprehensive and cover all the processes of gathering tax information, identifying the tax liability and collection of taxes.

Moreover, tax administration and administrative law are inadvertently in a need of being completed by private law. Civil law principles can be helpful to guide both taxpayers and tax authorities, for example where it is important to interpret what the proper way of exercising taxpayer rights means in specific circumstances. Where tax authorities are not explicitly authorised by statutory law to act, they must rely on the principles that are in accordance with the constitutional order. In a country with a market economy and a system of political democracy, competences need be established on the subsidiarity principle and legal obligations need eventually be assessed, based on the principle of "pacta sunt servanda". This means that the final criterion according to which even the actions of public administration can be assessed is whether it is reasonable for a public authority to act, and if so, whether it has observed any contractual obligations. Notably, in Hungary, there is no statutory law that would preclude the universal effect of the Civil Code, covering all the financial relations whether to be made between private persons or between private persons and the representative of the public.

Finally, for the purposes of approximating an ideal tax system, the possibility of horizontal coordination must not be left out of consideration. Businesses have to encounter the problem that they have been internationalized while the legal and tax systems operate basically in isolation from each other. The nation state is not able longer to provide contracting parties entering international markets with sufficient legal munitions. These parties are then compelled to start negotiating a legal background (a set of the rules of game) on the basis of which they can find coherence and legal certainty. Under these circumstances, law can be understood all the more from the conduct of the parties who have followed legal rules and related norms. Objective law can then be explored in its entirety subsequently, from the study of the conduct of parties. In this 
context, legal and tax planning and the choice of legal and tax regimes by parties have come to the forefront. Bargaining (e.g., advance ruling) has not been strange from tax law either. It is another example for alternatives in tax law that the tax liability can be determined in all the more instances depending on the taxpayer's choice. 